\title{
Research on Objective Environmental Factors of Sustainable Development of Enterprises in Qaidam Circular Economy Pilot Area
}

\author{
Wenjiao $\mathrm{Cai}^{1 *}$, Jianjun Wang ${ }^{1 *}$ \\ ${ }^{1}$ Qinghai University, Xining City, Qinghai Province, China
}

\begin{abstract}
The sustainable development of the industrial enterprises in the Qaidam Circular Economy Pilot Zone must meet both the current needs and the future development, as well as the economic and ecological development, as well as the dual development of industrial enterprises and regions. For the industrial enterprises in the experimental area, in order to ensure sustainable development, their own strategies and efforts are very important, but in a policy-dependent area like Haixi Prefecture, the influencing factors of the objective environment are more important. The impact of sustainable development of HaiXi industrial enterprises is of great practical significance. Therefore, according to the subjectivity of Haixi Prefecture and the experimental area and the nature of industrial enterprises, the objective environmental factors are divided into four categories: regional development, regional material resources, regional greening, and regional security. In the end, it was concluded that industrial enterprises in the test area not only need to pay attention to the restraint of their sustainable development in terms of brain drain, energy consumption and environmental greening, but also continue to maintain the role of regional development and regional security in promoting their sustainable development.
\end{abstract}

\section{Introduction}

Sustainable development refers to both meeting current needs and not weakening future development, that is economic development and ecological development. For industrial enterprises in the Qaidam Circular Economy Pilot Zone (hereinafter referred to as the "test zone"), sustainable development is not only the two, but also requires the development of both industrial enterprises and regions.

The Qaidam Circular Economy Pilot Zone is located in Haixi Prefecture, Qinghai Province. According to the 2018 National Economic and Social Development Statistical Communiqué of Haixi Prefecture, the gross industrial output value of Haixi Prefecture 's secondary industry is 42.84 billion yuan, accounting for $68.5 \%$ of the total regional GDP, driving economic growth by 5.3 percentage points. As the largest cluster of enterprises in Haixi Prefecture and the largest number of enterprises, the test area is the main source of economic resources in Haixi Prefecture. The number of industrial enterprises in the test area occupies the majority of the enterprises in the test area. It is also the main economic source of the test area and the main source of production in Haixi Prefecture. Therefore, the sustainable development of industrial enterprises in the research experimental area is the sustainable development in the research experimental area and Haixi Prefecture, which is very beneficial to regional development. In addition, for the industrial enterprises in the experimental area, in order to ensure sustainable development, their own strategies and efforts are very important, but in a policy-dependent area like Haixi Prefecture, the influencing factors of the objective environment are more important, so the objective environmental factors are studied the impact on the sustainable development of industrial enterprises in Haixi Prefecture is of great practical significance [1].

To sum up, according to the subjectivity of Haixi Prefecture and the experimental area and the nature of industrial enterprises, the objective environmental factors are divided into four categories: regional development, regional material resources, regional greening, and regional security [2-5].

\section{Empirical research}

\subsection{Index selection}

The factors affecting the sustainable development of industrial enterprises in the Qaidam Circular Economy Pilot Zone can be divided into endogenous and exogenous factors, and can also be called subjective and objective factors. This article focuses on the objective environmental factors in the development of enterprises in the Qaidam Circular Economy Pilot Zone. It is roughly divided into four categories: regional development, regional environment, regional material 
resources, and regional services. In order to ensure the integrity of the system and the availability of data, the four categories are divided into the following indicators in Table 1. It is worth noting that the Qaidam Circular Economy Pilot Zone is located in Haixi Prefecture, Qinghai Province, which is the main source of production and a key support object of Haixi Prefecture. The industrial enterprises in the test area are the main enterprise groups in the test area and the main source of secondary industry in Haixi Prefecture. In addition,
Haixi's regional GDP, fiscal revenue, degree of urbanization, total annual energy consumption, total annual power consumption, total industrial wastewater discharge, total industrial exhaust emissions, and total industrial solid waste emissions are approximately equal to the data of the test area, and the social security expenditure, health care expenditure, education expenditure and fiscal expenditure of Haixi Prefecture are to ensure the normal operation of Haixi Prefecture, so they are due for the normal operation of the Test District.

Table 1.Index system

\begin{tabular}{|c|c|c|c|c|}
\hline \multicolumn{2}{|c|}{ Classification } & Index & Assignment & Description \\
\hline \multicolumn{2}{|c|}{ Dependent variable } & $\begin{array}{l}\text { Total production of the secondary } \\
\text { industry (100 million yuan) }\end{array}$ & Y & $\begin{array}{l}\text { The enterprises in the Q aidam } \\
\text { Circular E conomy Pilot Zone are } \\
\text { mainly engaged in the development of } \\
\text { secondary industries, so this indicator } \\
\text { is selected. }\end{array}$ \\
\hline \multirow{11}{*}{$\begin{array}{l}\text { Independent } \\
\text { variable }\end{array}$} & $\begin{array}{l}\text { Objective } \\
\text { environmental } \\
\text { factors of }\end{array}$ & Regional GDP (100 million yuan) & $X 1$ & $\begin{array}{l}\text { The GDP of Haixi Prefecture, Qinghai } \\
\text { Province is approximately equal to the } \\
\text { test area[6] }\end{array}$ \\
\hline & & Financial revenue (ten million yuan) & $\begin{array}{l}\times 2 \\
\times 3\end{array}$ & Can reflect policy guidance[7] \\
\hline & Objective & Total annual energy consumption & A J & \\
\hline & $\begin{array}{l}\text { environmental } \\
\text { factors of } \\
\text { regional } \\
\text { material } \\
\text { resources }\end{array}$ & $\begin{array}{l}\text { (tons / standard coal) } \\
\text { A nnual total power consumption } \\
(\mathrm{kWh})\end{array}$ & $\times 5$ & $\begin{array}{c}\text { M aterial consumption of industrial } \\
\text { enterprises is mainly energy and } \\
\text { electricity }\end{array}$ \\
\hline & Obiective & Total industrial wastewater discharge & $x 6$ & Although the "three wastes" are \\
\hline & environmental & $\begin{array}{l}\text { (10,000 tons) } \\
\text { Tatriol ins }\end{array}$ & & emissions from industrial enterprises, \\
\hline & factors of & $\begin{array}{l}\text { (tons) } \\
\text { (tal tomissions }\end{array}$ & $\times 7$ & protection and maintenance of the \\
\hline & greening & $\begin{array}{l}\text { Total industrial solid waste emissions } \\
\qquad(10,000 \text { tons })\end{array}$ & $\times 8$ & $\begin{array}{l}\text { local environment by local policies } \\
\text { from the side [9]. }\end{array}$ \\
\hline & $\begin{array}{l}\text { Objective } \\
\text { environmental }\end{array}$ & $\begin{array}{l}\text { Proportion of social security } \\
\text { expenditure to fiscal expenditure }\end{array}$ & $\times 9$ & $\begin{array}{l}\text { Social Security provides employment } \\
\text { logistics }\end{array}$ \\
\hline & factors of & $\begin{array}{l}\text { Proportion of health expenditure to } \\
\text { fiscal expenditure }\end{array}$ & $X 10$ & $\begin{array}{c}\text { M edical health guarantees human } \\
\text { health }\end{array}$ \\
\hline & $\begin{array}{l}\text { regional } \\
\text { security }\end{array}$ & $\begin{array}{l}\text { Education expenditure as a percentage } \\
\text { of fiscal expenditure }\end{array}$ & $\mathrm{X} 11$ & $\begin{array}{c}\text { Education can cultivate human } \\
\text { resources }\end{array}$ \\
\hline
\end{tabular}

\subsection{Data}

Table 2.Data Table of Objective Influencing Factors for Enterprise Development in the Q aidam Circular Economy Pilot A rea

\begin{tabular}{ccccccccccccc}
\hline & $\mathrm{Y}$ & $\mathrm{X} 1$ & $\mathrm{X} 2$ & $\mathrm{X} 3$ & $\mathrm{X} 4$ & $\mathrm{X} 5$ & $\mathrm{X} 6$ & $\mathrm{X} 7$ & $\mathrm{X} 8$ & $\mathrm{X} 9$ & $\mathrm{X} 10$ & $\mathrm{X} 11$ \\
\hline 2005 & 100.12 & 134.34 & 128.55 & 0.62 & 200.52 & 20.43 & 0.92 & 0.95 & 0.95 & 0.06 & 0.04 & 0.11 \\
2006 & 130.07 & 169.74 & 188.09 & 0.61 & 266.12 & 18.76 & 0.86 & 0.85 & 0.85 & 0.07 & 0.04 & 0.09 \\
2007 & 156.11 & 202.36 & 282.13 & 0.61 & 393.35 & 24.78 & 0.79 & 0.66 & 0.77 & 0.14 & 0.06 & 0.10 \\
2008 & 218.96 & 275.07 & 371.38 & 0.61 & 520.21 & 21.55 & 0.68 & 0.51 & 0.67 & 0.15 & 0.05 & 0.12 \\
2009 & 228.23 & 291.78 & 440.32 & 0.61 & 540.55 & 22.34 & 0.54 & 0.54 & 0.68 & 0.18 & 0.06 & 0.12 \\
2010 & 288.97 & 365.49 & 344.92 & 0.61 & 585.62 & 26.13 & 0.36 & 0.47 & 0.63 & 0.14 & 0.06 & 0.11 \\
2011 & 390.71 & 481.40 & 391.47 & 0.70 & 658.07 & 33.08 & 0.27 & 0.22 & 0.19 & 0.09 & 0.05 & 0.13 \\
2012 & 464.04 & 570.33 & 449.07 & 0.72 & 763.79 & 40.62 & 0.27 & 0.28 & 0.18 & 0.08 & 0.04 & 0.16 \\
2013 & 433.94 & 553.23 & 491.14 & 0.92 & 720.69 & 49.52 & 0.24 & 0.26 & 0.16 & 0.11 & 0.06 & 0.13 \\
2014 & 380.24 & 512.29 & 493.76 & 0.92 & 745.89 & 59.95 & 0.24 & 0.22 & 0.17 & 0.10 & 0.05 & 0.11 \\
2015 & 297.03 & 439.85 & 507.19 & 0.69 & 954.47 & 71.02 & 0.20 & 0.09 & 0.09 & 0.12 & 0.06 & 0.10 \\
2016 & 326.67 & 486.96 & 452.24 & 0.69 & 1037.22 & 68.91 & 0.10 & 0.21 & 0.10 & 0.13 & 0.06 & 0.10 \\
2017 & 349.66 & 508.85 & 458.57 & 0.72 & 1183.93 & 82.50 & 0.45 & 0.62 & 0.19 & 0.27 & 0.65 & 0.12 \\
\hline
\end{tabular}

Data source: 2005-2017 related data in Haixi State Statistical Yearbook 2006-2018 


\subsection{Model establishment}

The data in Table 2 was analyzed by SPSS. The statistical results show that all independent variables are considered within the range, and they affect and determine the dependent variable together. Then continue to check the model fit. It can be seen from the model summary in Table 3 that the correlation coefficient $\mathrm{R}$ is 1.000 , the determination coefficient $\mathrm{R}$ is 1.000 , and the adjusted $\mathrm{R}$ square is 0.999 , which indicates that the model established is highly fit. Using this model can basically explain the development of industrial enterprises in the test area.

Table 3.M odel summary

\begin{tabular}{ccccc}
\hline model & $\mathrm{R}$ & R side & Adjusted R-squared & Standard estimation error \\
\hline 1 & 1.000 & 1.000 & 0.999 & 2.66890 \\
a. Dependent variable: $y$ & & & \\
Table data source: SPSS software data analysis & & \\
\hline
\end{tabular}

Then perform the variance test. From Table 4, for a given significance level $\mathrm{a}=0.05$, the $\mathrm{F}$ critical value is $\mathrm{Fa}(\mathrm{k}, \mathrm{nm}-1)=\mathrm{F} 0.05(11,1), \mathrm{F}=2075.987>\mathrm{F} 0.05(11,1)$
$=242.983$, so rejecting the null hypothesis, the linear relationship between the variables is significant.

Table 4.A NOV A ${ }^{a}$ table

\begin{tabular}{ccccccc}
\hline model & & sum of square & Degrees of freedom & Mean square & F & Sig. \\
\hline 1 & return & 162660.189 & 11 & 14787.290 & 2075.987 & $.017 \mathrm{~b}$ \\
Residual & 7.123 & 1 & 7.123 & & \\
total & 162667.312 & 12 & & & \\
\multicolumn{2}{l}{ a. Dependent variable: $y$} & & & & \\
Table data source: SPSS software data analysis
\end{tabular}

Secondly, according to the regression data in Table 5, regression coefficients. the regression equation is constructed by using the

Table 5.T able of regression coefficients

\begin{tabular}{|c|c|c|c|c|c|c|}
\hline \multirow{2}{*}{\multicolumn{2}{|c|}{ model }} & \multicolumn{2}{|c|}{ Unstandardized coefficient } & \multirow{2}{*}{$\begin{array}{c}\text { Normalization coefficient } \\
\text { Beta }\end{array}$} & \multirow{2}{*}{$\mathrm{t}$} & \multirow{2}{*}{ Saliency } \\
\hline & & $\mathrm{B}$ & Standard error & & & \\
\hline \multirow{12}{*}{1} & (constant) & 25.208 & 32.483 & & 0.776 & 0.580 \\
\hline & $\mathrm{X} 1$ & 1.049 & 0.081 & 1.378 & 12.891 & 0.049 \\
\hline & $\mathrm{X} 2$ & 0.003 & 0.037 & 0.003 & 0.090 & 0.943 \\
\hline & $\mathrm{X} 3$ & -83.644 & 41.580 & -0.078 & -2.012 & 0.294 \\
\hline & $\mathrm{X} 4$ & -0.141 & 0.051 & -0.349 & -2.775 & 0.220 \\
\hline & $\mathrm{X} 5$ & -3.44 & 0.398 & -0.066 & -0.863 & 0.547 \\
\hline & X6 & 44.378 & 23.423 & 0.105 & 1.895 & 0.309 \\
\hline & $\mathrm{X} 7$ & -37.612 & 21.585 & -0.086 & -1.742 & 0332 \\
\hline & $\mathrm{X} 8$ & 2.348 & 25.838 & 0.007 & 0.091 & 0.942 \\
\hline & $\mathrm{X} 9$ & 90.833 & 106.507 & 0.044 & 0.853 & 0.550 \\
\hline & $\mathrm{X} 10$ & 22.769 & 32.066 & 0.033 & 0.710 & 0.607 \\
\hline & X11 & 66.884 & 149.774 & 0.011 & 0.447 & 0.733 \\
\hline \multicolumn{7}{|c|}{ a. dependent variable: y } \\
\hline \multicolumn{7}{|c|}{ Data source: SPSS analysis } \\
\hline
\end{tabular}

From Table 4, the multiple regression linear equation can be obtained:

$\mathrm{Y}=1.049 \mathrm{X} 1+0.003 \mathrm{X} 2-83.644 \mathrm{X} 3-0.141 \mathrm{X} 4-0.344 \mathrm{X} 5+$ $44.378 \times 6-37.612 \times 7+2.348 \times 8+90.833 \times 9+22.769 \times 10+6$ $6.884 \times 11$

\section{4 model checking}

Finally, the model is statistically tested:

Fitness test: R2 $=1.000$, high fit;

$F$ test: according to Table 3, given the significant level $\mathrm{a}=0.05$, the critical value of $\mathrm{F}$ is $\mathrm{Fa}(\mathrm{k}, \mathrm{nm}-1)=\mathrm{F} 0$. $05(11,1), F=2075.987>$ F0. $05(11,1)=242.983$, so rejecting the null hypothesis, the linear relationship between the variables is significant.

\section{Main conclusions}

\subsection{Objective environmental factors to promote sustainable development of industrial enterprises in the pilot zone}

Economic development, policy guidance, industrial wastewater discharge, industrial solid waste discharge, and regional guarantees in Haixi Prefecture of Qinghai Province have a positive effect on the sustainable 
development of industrial enterprises in the pilot zone. Among them, the promotion of objective environmental factors related to regional security is greater than the promotion of objective environmental factors related to regional greening and regional development. Of the three factors, the objective environmental factors related to regional development have the smallest promotion effect.

\subsection{Objective environmental factors that inhibit the sustainable development of industrial enterprises in the pilot zone}

The level of urbanization, consumption of resources, and emissions of industrial waste gases in Haixi Prefecture of Qinghai Province have a negative inhibitory effect on the sustainable development of industrial enterprises in the pilot zone. Among them, the objective environmental factors in the material resources of the Haixi Prefecture are generally inhibiting, which indicates that the more material resources are consumed, the worse the development prospects of industrial enterprises relying on material resources are, which ultimately makes the industrial enterprises' sustainable development level low. At the same time, the objective environmental factors related to regional development should theoretically all promote the sustainable development of industrial enterprises, but the level of urbanization is inhibiting development, and the degree of inhibition is not low, mainly because of the geographical location of Haixi Prefecture and Economic development is not ideal. Even if the urban residents of Haixi Prefecture are preparing for moving to other cities, especially Xining City, this phenomenon leads to a higher level of urbanization in Haixi Prefecture. In addition, the higher the total industrial exhaust emissions in Haixi Prefecture, the more inhibited the degree of sustainable development of industrial enterprises in the test area. This is because since 2010, the test area became a national-level circular economy test area, and more attention has been paid to the coordinated development of industrialization and greening. The total amount of industrial exhaust emissions is more likely to exceed the standard than industrial wastewater and industrial solid waste, reducing the test The degree of greening in the zone makes the management committee of the test zone increase its management, control the level of greening and reduce the industrial level of the test zone, and ultimately reduce the sustainable development level of the industrial enterprises in the test zone.

\section{Conclusion}

The industrial enterprises in the Qaidam Circular Economy Pilot Zone have rich material resources and vast plant land, and have good development prospects. However, in order to ensure the sustainable development of industrial enterprises, in addition to their own strategic layout and unremitting efforts, they should also pay attention to the following objective environmental factors: First, we need to strengthen the control of brain drain and change the purpose of urbanization so that the development of urbanization is no longer the first step in the brain drain of industrial enterprises, but the first step in retaining foreign talents in industrial enterprises or strengthening the protection of local talents, improving personnel security, welfare and treatment, and ultimately strengthening the softness of sustainable development of industrial enterprises. Secondly, it is necessary to reasonably arrange the energy consumption of industrial enterprises in the experimental area, which is no longer an uncontrolled and non-circular waste, but is used purposefully and in demand to improve the repeated utilization of regional material resources and increase the degree of regional greening. The development of enterprises improves a steady stream of material resources, and finally achieves the sustainable development of industrial enterprises. Thirdly, attention should be paid to the degree of environmental greening in the test area, and the environmental protection and industrial development of the test area should be organically combined, so that the two complement and complement each other to ensure the sustainable development of industrial enterprises in the test area. Finally, it is necessary to continue to maintain regional development and regional guarantees, and provide logistical and service guarantees to industrial enterprises in the pilot areas. The sustainable development of the industrial enterprises in the Qaidam Circular Economy Pilot Zone is not only the sustainable development of the enterprise, but also the sustainable development of the pilot zone, but also the sustainable development of Haixi Prefecture and Qinghai Province. We should combine the protection of the environment with the development of production, the combination of present and future development, the combination of enterprise development and regional development, and ultimately achieve the goal of symbiosis and win-win.

\section{References:}

1. Luo Xuan. A Study on the Agglomeration Models of Factors Driving Economic Development in Ethnic Areas [J]. Guizhou Ethnic Studies, 2017, 38 (8): 188-192.

2. Wang Hongyu, Liu Kan, Fan Decheng. Are regional industrial development and resource endowments synergistic? - Based on the perspective of industry, factors, and technical resources [J]. Operations Research and Management Science, 2019 (5): 117-123.

3. Hui Tiaoyan, Guo Xiao. Measurement of the Coordinated Development Level of Economy, Resources and Environment in the Western Region [J]. Statistics and Decision, 2019 (11).

4. Li Jian, Wang Yao, Wang Ying. Decoupling Status and Driving Factors of Regional Economic Development and Resources and Environment in Beijing-Tianjin-Hebei Region [J]. Economic Geography, 2019 (4).

5. Zhao Jianguo, Liao Zangyi, Li Jia. A Study on the Regional Equity of the Social Security Fiscal 
Burden in China and Its Influencing Factors [J]. Financial Research, 2016 (10): 49-57.

6. Wang Xuexue. An Empirical Analysis of the Factors Affecting China's Regional GDP [J]. Time Finance, 2017 (15).

7. Meng Jinglei, Xiu Guoyi. An Empirical Analysis of the Relationship between Local Fiscal Revenue and Economic Growth [J]. Statistics and Decision, 2019 (16): 171-175.

8. Xie Fangfang. Empirical research on technological innovation, openness and upgrading of the secondary industry [D]. 2017.

9. Qin Jieqiong, Sun Ruiling, Yu Zhonghua, et al. Analysis on the Trend and Decomposition of Industrial Pollution Emission in Nanjing [J]. Pollution Control Technology, 2019 (4). 